\title{
Effect of ClAIPcS 2 Photodynamic and Sonodynamic Therapy on HeLa Cells
}

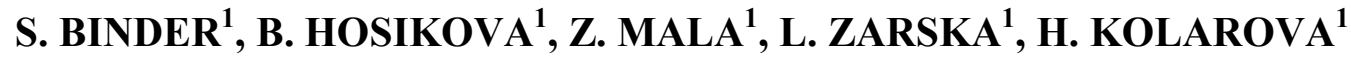 \\ ${ }^{1}$ Department of Medical Biophysics, Faculty of Medicine and Dentistry, Institute of Molecular and \\ Translational Medicine, Palacky University, Olomouc, Czech Republic
}

Received October 6, 2019

Accepted October 31, 2019

\begin{abstract}
Summary
Photodynamic therapy (PDT) uses photosensitive substance to provoke a cytotoxic reaction causing a cell damage or cell death. The substances, photosensitizers, are usually derivates of porphyrine or phtalocyanine. Photosensitizers must be activated by light in order to produce reactive oxygen species, mainly singlet oxygen. Sonodynamic therapy (SDT) utilizes ultrasound to enhance a cytotoxic effects of compounds called sonosensitizers. In this study we investigated photodynamic and sonodynamic effect of chloraluminium phtalocyanine disulfonate $\left(\mathrm{CIAIPCS}_{2}\right)$ on HeLa cells. DNA damage, cell viability and reactive oxygen species (ROS) production were assessed to find whether the combination of PDT and SDT inflicts HeLa cells more than PDT alone. We found that the combined therapy increases DNA fragmentation, enhances ROS production and decreases cell survival. Our results indicate that $\mathrm{CIAIPCS}_{2}$ can act as a sonosentitiser and combined with PDT causes more irreversible changes to the cells resulting in cell death than PDT alone.
\end{abstract}

\section{Key words}

$\mathrm{ClAIPCS}_{2} \bullet \mathrm{PDT} \bullet \mathrm{SDT} \bullet \mathrm{HeLa} \bullet \mathrm{ROS} \bullet \mathrm{MTT}$ assay • DNA • Comet assay

\section{Corresponding author}

S. Binder, Department of Medical Biophysics, Faculty of Medicine and Dentistry, Institute of Molecular and Translational Medicine, Palacky University, Hnevotinska 3, 77515, Olomouc, Czech Republic. E-mail: svatopluk.binder@email.cz

\section{Introduction}

Photodynamic therapy (PDT) is an alternative method of tumor treatment. It is based on a photochemical reaction of a photosensitizer, irradiation, and $\mathrm{O}_{2}$ which converts to cytotoxic ${ }^{1} \mathrm{O}_{2}$ and other forms of reactive oxygen species (ROS) (Östling and Johanson 1984). Each photosensitizer can be activated by a light of appropriate wavelength corresponding with its absorption maximum. Molecules of the photosensitizer are designed to be selectively retained by tumour tissue while leaving healthy tissues intact. There are two types of photochemical reaction between light and the photosensitizer following transition from ground to triplet state of the photosensitizer after the light absorption, type I and type II. In the type I free radicals and other reactive oxygen species are formed after absorption of energy in water molecule while in the type II the energy is used to give rise to highly toxic singlet oxygen.

Sonodynamic therapy (SDT) is a similar procedure using ultrasound as another modality to produce cytotoxic effects. Ultrasound bioeffects normally associated with exposure are heat, mechanical effects and acoustic cavitation. These effects are intensity and frequency dependant. A higher intensity favours heatproduction while lower frequencies result in cavitations (Yu et al. 2004).

Ultrasound, in contrast to irradiation, can penetrate deeply into the tissues and activate the sonosensitizing substances. It can also trigger ultrasound waves directly to the tumour location not damaging surrounding cells. Low intensity ultrasound using waves around 1.5 MHz can also increase the cell permeability and thus allowing the sonosensitising or photosensiting substances easily penetrate into the cell (Meng et al. 2008). The cytotoxic effect of SDT is assumed to be caused by internal cavitations followed by the formation 
of free radicals (Tice et al. 2000). This cavitationinduced damage can be reduced by free radical scavengers and antioxidants like mannitol, vitamin $\mathrm{C}$ or superoxide dismutase (Yu et al. 2003)

Reactive oxygen species (ROS) are naturally produced by oxygen metabolism and play an important role in cell signalling and homeostasis (Devasagayam et al. 2004). Under normal condition the amount of ROS is balanced with antioxidant ability of ROS scavenging system of the cells but when the organism is exposed to stress the number of ROS significantly increases which can lead to oxidative stress causing either cell impairment or cell death. ROS may cause DNA damage, lipid peroxidation or oxidation of protein amino acids (Brooker 2011).

The comet assay (also called single-cell gel electrophoresis, SCGE) is a sensitive, simple and quantitative technique for detection of DNA damage. In 1984, Swedish researchers Östling and Johanson (1984) were the first to introduce this assay under neutral conditions. Few years later, this electrophoretic method was modified for use under alkaline conditions (Singh et al. 1988). The comet assay is based on the ability of negatively charged fragments of the DNA to be drawn through an agarose gel in response to an electric field. The extent of DNA migration depends directly on the DNA damage in the cells (Kumaravel et al. 2009). The comet assay can be used for the detection and quantification of damage such as single and double strand DNA breaks or DNA repair (Heaton et al. 2002).

The DNA damage is qualitatively presented by the amount of the unwound DNA fragments which resembles a "comet, having a distinct head and tail (Heaton et al. 2002). The head consists of intact DNA, while the tail is created of broken fragments of DNA or relaxed chromatine. The amount of DNA damage is directly proportional to the amount of DNA liberated from the head (Collins 2004). The detection of altered DNA migration is dependent on various parameters such as the concentration of agarose gel, the $\mathrm{pH}$, temperature and duration of the alkaline unwinding agent, temperature, voltage, current and the duration of electrophoresis (Hartmann et al. 2003). The degree of DNA damage can be assessed automatically using either appropriate scoring software or by means of manual techniques.

Phtalocyanines present second generation of photosensitizers. They are structurally similar to porphyrins (Jiang et al. 2014). When coupled with zinc, silicon or aluminum as their central atom they exhibit high efficiency or ROS generation, high stability and low toxicity, high fluorescence which make them ideal photosensitizers. On the other hand, it should be noted their low water-solubility and tendency to aggregation (Sekkat et al. 2012).

In this study we investigated a synergic effect of PDT and SDT therapy of $\mathrm{ClAlPcS}_{2}$ phtalocyanine photosensitizer on HeLa cell line. We wanted to find whether a combination of PDT and SDT affects cell viability, ROS production and DNA damage of tumour cells more than PDT alone.

\section{Materials and Methods}

$3 \times 10^{5}$ HeLa cells cultivated in $35 \mathrm{~mm}$ Petri dishes using a Dulbecco's modified Eagle's medium, phosphate-buffered saline (DMEM) with addition of $10 \%$ fetal bovine serum (FBS)

were utilized as a biological material for the MTT viability/phototoxicity assay, reactive oxygen species measurement, mitochondrial membrane potential measurement and comet assay.

The chemicals used included $\mathrm{ClAlPcS}_{2}$ (chloraluminium phtalocyanine di-sulfonate) (prepared by Jan Rakusan at the Research Institute for Organic Syntheses in Rybitvi, Czech Republic), Dulbecco's Modified Eagle Medium (DMEM) (Sigma Aldrich), phosphate buffered saline (PBS, pH 7.4 own preparation) 5-(and-6)-chloromethyl-2', $7^{\prime}$-dichlorodihydrofluorescein diacetate (CM-H2DCFDA, Invitrogen Co., USA), 3-(4,5dimethyl-2-thiazolyl)-2,5-diphenyl-2H-tetrazolium bromide (MTT, Sigma Aldrich), HMP agarose (Serva, Biotech, Czech Republic), LMP agarose (Qbiogene, Genetica, Czech Republic), Trypsin (Sigma Aldrich), fetal bovine serum (FBS, Sigma Aldrich), $\mathrm{NaCl}$ (Tamda, Czech Republic), EDTA (ethylenediaminetetraaceticacid, Lachema, Czech Republic), Tris (tris(hydroxymethyl) aminomethane, Sigma Aldrich), Triton X-100 (Serva), $\mathrm{NaOH}$ (Sigma Aldrich) SYBR Green (Invitrogen Co, USA), dimethyl sulfoxide (DMSO, Sigma Aldrich).

The photosensitizer $\mathrm{ClAlPcS}_{2}$ at concentrations of $0.5,1,5$ and $10 \mu \mathrm{M}$ was added to the Petri dish and the cells were incubated in a thermobox at $37^{\circ} \mathrm{C}$ and $5 \% \mathrm{CO}_{2}$ atmosphere for 24 hours. Two Petri dishes were used as controls (neither sonodynamically or photodynamically treated cells in the absence of the photosensitizer). DMEM was replaced by PBS containing $5 \mathrm{mM}$ glucose prior to the experiment. The Petri dishes 
with the cells were placed in a tank filled with distilled water at $37{ }^{\circ} \mathrm{C}$. A BTL 4000 device (BTL zdravotnická technika, s.r.o., Czech Republic) was used as the source of ultrasound.

We executed two types of experiment. In the first experiment we exposed samples only to the photodynamic therapy, in the other the photodynamic therapy followed after the ultrasound exposure. The cells were exposed for $10 \mathrm{~min}$ to the ultrasound with the Petri dishes at distance of $5 \mathrm{~cm}$ from a $4 \mathrm{~cm}$ diameter transducer which produces a continuous wave ultrasound of $1 \mathrm{MHz}$ frequency and acoustic intensity of $2 \mathrm{~W} / \mathrm{cm}^{2}$. PDT was carried out by using LEDs with the emission maximum at $660 \mathrm{~nm}$ as the source of radiation with a total radiation dose of $15 \mathrm{~J} / \mathrm{cm}^{2}\left(15 \mathrm{~mW} / \mathrm{cm}^{2}, 1000 \mathrm{~s}\right)$.

\section{MTT Assay}

The cells were irradiated and a fresh DMEM was replaced. The cells were then incubated for 24 hours at $37{ }^{\circ} \mathrm{C}$ and $5 \% \mathrm{CO}_{2}$ atmosphere. Subsequently the cells were incubated for 4 hours with $0.5 \mathrm{mg} / \mathrm{ml}$ MTT (3-(4, 5dimethylthiazol-2-yl)-2, 5-diphenyltetrazolium bromide) dissolved in DMEM, and then the medium was discarded and replaced by $100 \mu \mathrm{l}$ of DMSO leading to formazan crystals dissolution. The concentration of formazan coloured crystals is measured spectrophotometrically at absorbance $570 \mathrm{~nm}$ and cell viability is evaluated.

\section{Reactive oxygen species (ROS) Measurement}

2', 7'-Dichlorodihydrofluorescein diacetate $\left(\mathrm{DCFH}_{2}\right)$ was selected as a fluorescence probe for detection of ROS production. $\mathrm{DCFH}_{2}$ oxidation as a result of interaction with ROS yields fluorescent 2', 7'-dichlorofluorescein (DCF). The sample cells were incubated with the $20 \mu \mathrm{M}$ working concentration for $20 \mathrm{~min}$ and the resulting fluorescence was measured.

\section{Mitochondrial membrane potential}

Mitochondrial membrane potential $\Delta \Psi \mathrm{m}$ was measured by using the fluorescent probe JC-1(5,5',6,6'tetrachloro-1,1',3,3' tetraethylbenzimidazolylcarbo-cyanine chloride) that accumulates in mitochondria. The greenfluorescent JC-1 $(530 \mathrm{~nm})$ probe exists as a monomer at low concentrations or at low membrane potential. At higher concentrations or higher mitochondrial potentials, JC-1 forms red-fluorescent "J-aggregates" with emission maximum at around $590 \mathrm{~nm}$. Thus, the emission of this cyanine dye can be used as a sensitive measure of mitochondrial membrane potential. Immediately after irradiation (sonification) the cells were incubated with
PBS media with JC-1 at the final assay concentration of $2 \mu \mathrm{g} / \mathrm{ml}$ for $20 \mathrm{~min}$ at $37^{\circ} \mathrm{C}, 5 \% \mathrm{CO}_{2}$ and that washed by PBS. Results were expressed as the ratio of green to red fluorescence $(530 / 590 \mathrm{~nm})$.

\section{Comet assay}

The DNA damage was studied by applying the comet assay. Microscope slides were first precoated with $1 \%$ HMP (high melting point) agarose in distilled $\mathrm{H}_{2} \mathrm{O}$ and then placed in a drying oven at a temperature of $60{ }^{\circ} \mathrm{C}$ for at least $30 \mathrm{~min}$. Then $85 \mu \mathrm{l}$ of $1 \%$ HMP agarose in PBS was applied onto the precoated slides which were then covered with a cover slip. The slides were then placed in a refrigerator in order to enhance gelling of the agarose. The cells were trypsinized for $5 \mathrm{~min}$ to detach the cells from the bottom of the Petri dish. The trypsinisation was stopped by means of the fetal bovine serum (FBS). Isolated cells were centrifuged (6 min, $1000 \mathrm{rpm}$ ) then the cell pellet was dispersed in $20 \mu \mathrm{l}$ of PBS and vortexed. A quantity of $85 \mu \mathrm{l}$ of $1 \%$ LMP (low melting point) agarose was added to this solution and $85 \mu \mathrm{l}$ of this suspension was added to the microscope slide that had been prepared with the solidified agarose gel (the cover slip was removed prior to cell inoculation on the gel) and covered by a new glass cover slip to form a thin layer and moved to the refrigerator again. After solidifying the cover slips were removed again and the microscope slides were immersed in a lysis buffer $2.5 \mathrm{M}$ $\mathrm{NaCl}, 100 \mathrm{mM}$ EDTA (ethylenediamin-etetraaceticacid), $10 \mathrm{mM}$ Tris (tris(hydroxyl-methyl)aminomethane), $1 \%$ Triton $\mathrm{X}-100, \mathrm{pH}=10$ ) at $4{ }^{\circ} \mathrm{C}$ for at least 1 hour. After the lysis the slides were washed in distilled water to remove all salts and then placed in an electrophoretic tank and dipped into a cool electrophoresis solution $(300 \mathrm{mM}$ $\mathrm{NaOH}, 1 \mathrm{mM}$ EDTA) for $40 \mathrm{~min}$. Electrophoresis was run at $0.8 \mathrm{~V} / \mathrm{cm}$ and $380 \mathrm{~mA}$ for $20 \mathrm{~min}$. After the electrophoresis the slides were rinsed 3 times for $5 \mathrm{~min}$ with a neutralisation buffer $(0.4 \mathrm{M}$ Tris, $\mathrm{pH}=7.5)$ at $4{ }^{\circ} \mathrm{C}$. The samples were subsequently stained by SYBR Green and immediately scored.

\section{Statistical analysis}

The results were processed using software SPSS v. 15 (SPSS Inc., Chicago, USA). The data are presented as mean \pm SD of three independent experiments. The statistical significance was determined by an analysis of variance with ANOVA post hoc tests Dunnet (comparison with a control). Statistical analysis of the comet assay results was performed using Fisher exact tests with Bonferroni correction. $\mathrm{P}<0.05$ was considered statistically significant. 


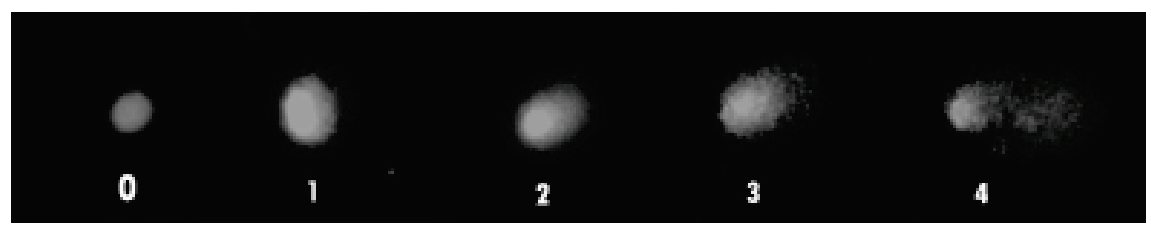

Fig. 1. Comet classes (0, 1, 2, 3 and 4) corresponding with the degree of DNA fragmentation.

\section{Results}

DNA damage of the cells was studied using comet assay. The samples were treated with PDT and with PTD followed by SDT. The 100 cells were randomly chosen from each sample. The cells were classified into 5 classes $(0,1,2,3$ and 4; Fig. 1) according to the length of their tail determining the degree of the DNA damage (8). The values corresponding with the comet classes for 100 cells were added up to obtain a total count (maximum total count equals to 400 , $4 \times 100)$. Typical shapes of head and tail of each comet class can be seen in Figure 1.

We found that total count for the $0.5 \mu \mathrm{M}$ concentration elicited only small DNA fragmentation for the cells treated only with PDT with prevailing comet classes number 1 and 2 whereas the cells treated with a PDT followed after SDT combination showed twice as high DNA damage. The concentrations of 5 and $10 \mu \mathrm{M}$ proved to have a profound effect on DNA fragmentation as the total count was close to its maximum which indicates almost all cells being in the comet class number 4 (Fig. 2). Significant changes in the DNA damage when comparing the both treatments used (Fig. 2) were only observed for 0.5 and $1 \mu \mathrm{M}$ concentrations $(85 \pm 15$ versus $190 \pm 6, \quad \mathrm{P}<0.05 ; 218 \pm 35$ versus $320 \pm 20, \quad \mathrm{P}<0.05, \quad$ respectively). Higher concentrations used elicited only marginal differences between the two treatments (PDT versus PDT followed after SDT). Cell viability was examined by the MTT test where the production of formazan corresponds with the number of living cells (Fig. 3). The MTT test was used to show whether or not the combination of PDT followed after SDT affects the cell viability of the treated cell. Spectrophotometric measurement showed that the cell viability decreased more in the cells treated with PDT followed after SDT, particularly for 0.5 and $1 \mu \mathrm{M}$ concentration of the photosensitizer used. For $1 \mu \mathrm{M}$ concentration the cell viability declined to $19 \pm 2 \%$ for the cells treated with PDT followed after SDT while the cell treated only with PDT showed $60 \pm 10 \%$ viability. Higher concentrations used yielded almost the same cell viability (below $10 \%$ survival) for both types of the treatment. EC 50 value for PDT treatment was calculated $0.53 \pm$ $0.07 \mu \mathrm{M}$ whereas the cells treated with both PDT followed after SDT showed EC 50 equaled to $1.61 \pm$ $0.23 \mu \mathrm{M}$ indicating pronounced effect of SDT and PDT combination on cell death. Ultrasound alone reduced the cell viability only by $10 \%$ whereas $\mathrm{ClAlPcS}_{2}$ caused only $3 \%$ decrease.

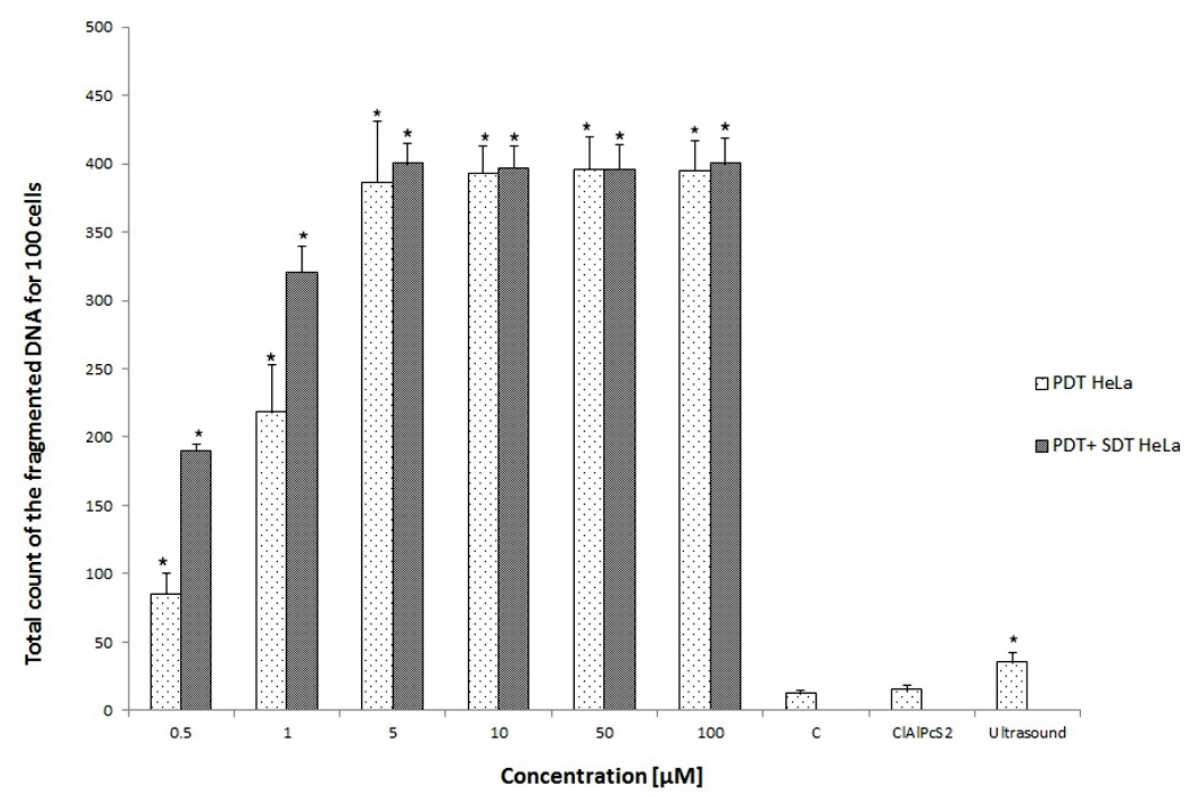

Fig. 2. Dependence of DNA fragmentation of HeLa cells loaded with different concentrations of $\mathrm{CIAIPCS}_{2}$ treated with either PDT or combination of PDT and SDT. Comet assay utilizes negative charge of DNA and allows DNA to be electro-phoretically separated resulting in a typical comet shape of fragmented DNA. The values represent total count of DNA comet classes for 100 cells. Each value represents mean \pm SE from 3 different expe-riments. Significant difference $(P<0.05)$ of the values to the control is marked by asterisk. 


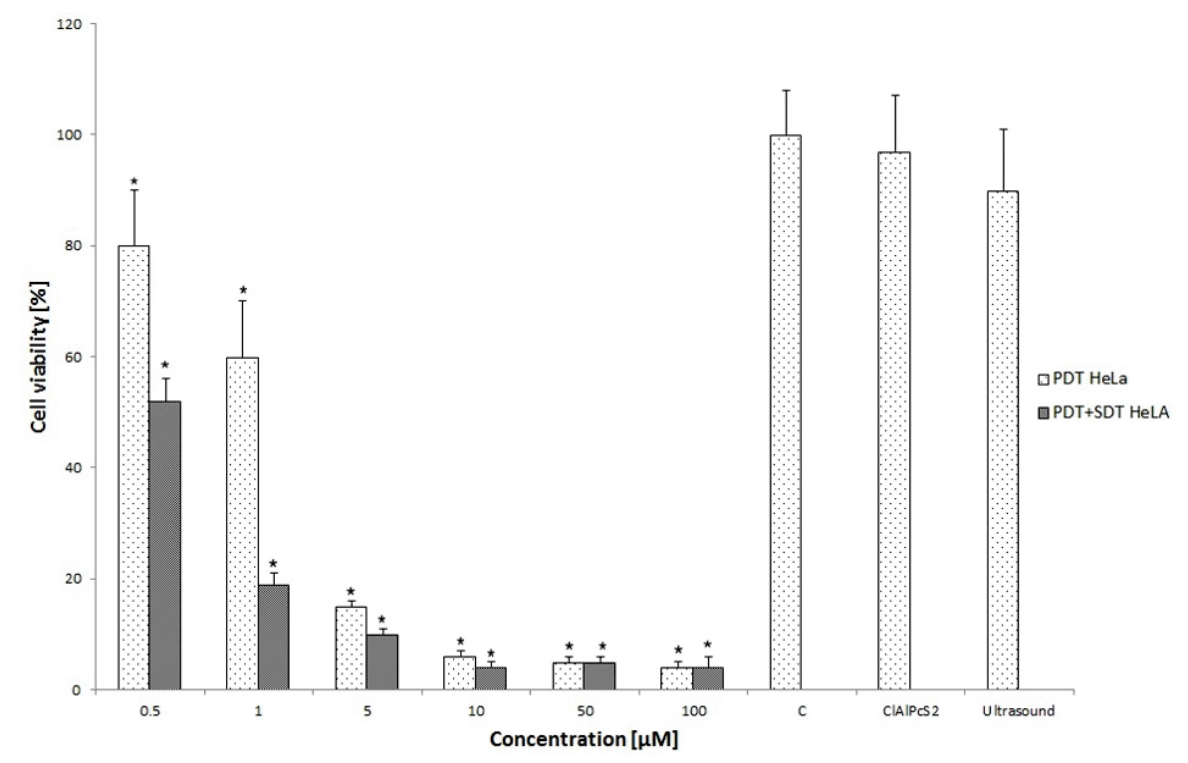

Fig. 3. Dependence of cell viability of HeLa cells loaded with different concentrations of $\mathrm{ClAIPCS}_{2}$ treated with either PDT or combination of PDT and SDT. The cell viability was measured spectrophotometrically by MTT where the absorbance of formazan is read. The values represent percentage of measured formazan absorbance compared to the absorbance of the control representing $100 \%$. Each value represents mean \pm SE from 3 different experiments. Significant differrence $(P<0.05)$ of the values to the control is marked by asterisk.

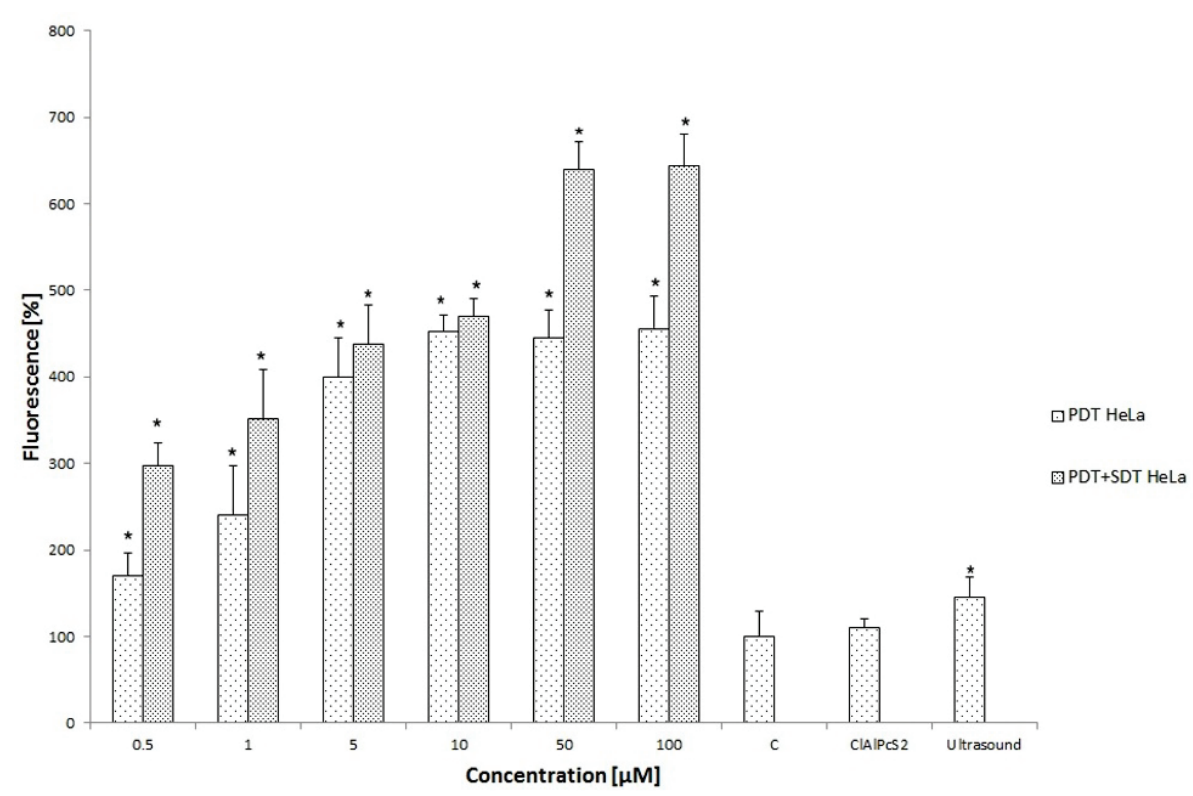

Fig. 4. Dependence of ROS production of HeLa cells loaded with different concentrations of $\mathrm{CIAIPCS}_{2}$ treated with either PDT or combination of PDT and SDT. ROS production was estimated by fluorescence probe $\mathrm{DCFH}_{2}$. Its oxidation as a result of interaction with ROS yields fluorescent DCF which values were recorded. The values represent percentage of measured fluorescence compared to the fluorescence of the control representing $100 \%$. Each value represents mean \pm SE from 3 different experiments. Significant difference $(P<0.05)$ of the values to the control is marked by asterisk.

Reactive oxygen species are the main product of photodynamic therapy. They interact with surrounding molecules and damage them which can lead to cell death. Our result show that ROS production increased for both the cells treated with PDT and also for the cells treated with PDT followed after SDT. We found that the cells treated with PDT followed after SDT exerted higher amount of ROS production compared to the cells treated only with PDT for the whole concentration range used (Fig. 4). The ROS production significantly increased for 0.5 and $1 \mu \mathrm{M}$ concentrations used when PDT followed after SDT treatment was applied compared to only PDT $(170 \pm 26 \%$ versus $297 \pm 31 \%, \mathrm{P}<0.05$ for $0.5 \mu \mathrm{M}$ and $240 \pm 56 \%$ versus $351 \pm 28 \%, \mathrm{P}<0.05$ for $1 \mu \mathrm{M})$. We did not observe any significant changes in ROS production for 5 and $10 \mu \mathrm{M}$ concentrations when comparing the two treatments used. Ultrasound alone produced nonsignificant $35 \%$ change in ROS production when compared to control untreated cells.

Mitochondrial membrane potential $(\Delta \psi \mathrm{M})$, is considered one of the key parameters of mitochondrial function used as an indicator of cell condition. The JC-1 probe was used to asses $\triangle \psi \mathrm{M}$ and the results are expressed as the ratio of green to red fluorescence. JC-1 is susceptible to oxidation by reactive oxygen species, and the resultant oxidized JC-1 may either lose fluorescence or show green instead of red fluorescence. It has been proposed that the opening of the mitochondrial membrane permeability transition pores, which results in the dissipation of the mitochondrial membrane potential 
( $\Delta \psi \mathrm{m})$. We found that $\Delta \psi \mathrm{m}$ increased for both the cells treated with PDT and also for the cells treated with PDT followed after SDT. We found that the cells treated with
PDT followed after SDT exerted higher amount of ROS production compared to the cells treated only with PDT for the whole concentration range used (Fig. 5).

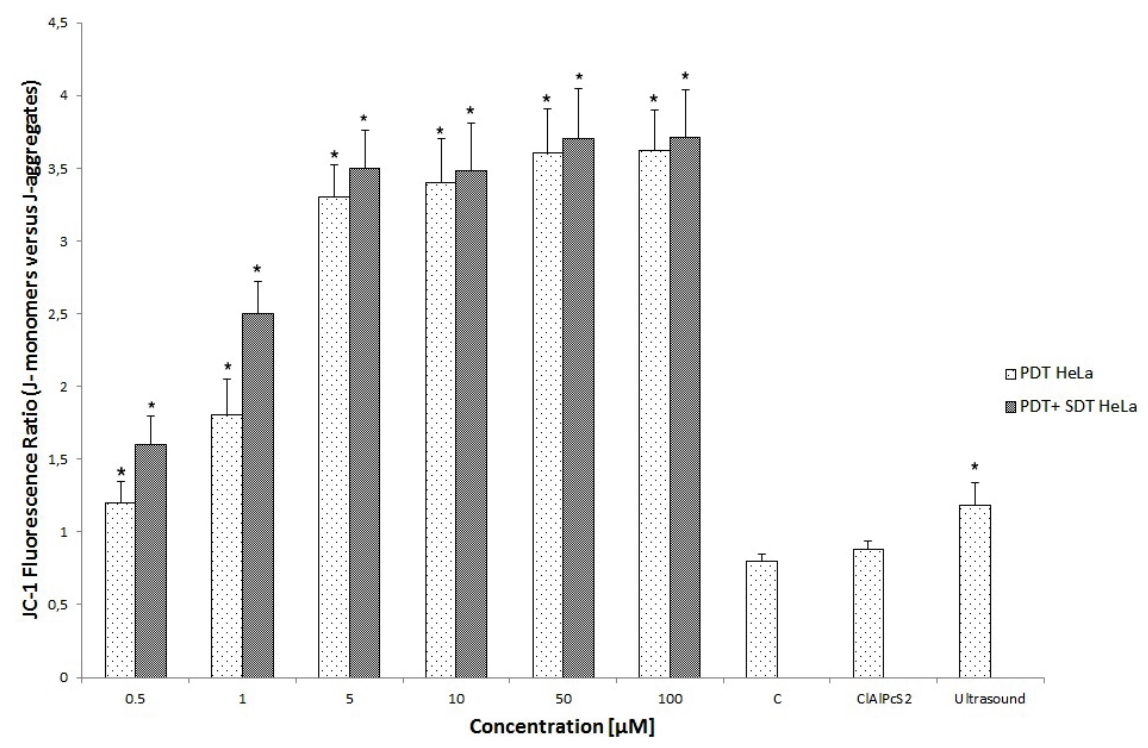

Fig. 5. Mitochondrial membrane potential change $(\Delta \psi M)$ of HeLa cells loaded with different concentrations of $\mathrm{ClAIPCS}_{2}$ treated with either PDT or combination of PDT and SDT. The values represent JC-1 fluorescence ratio (J-monomers versus J-aggregates) compared to the control being equal to 1 . Each value represents mean \pm SE from 3 different experiments. Significant difference $(P<0.05)$ of the values to the control is marked by asterisk.

\section{Discussion}

PDT is a promising method in cancer treatment which involves administration of a tumour-localizing photosensitizer followed by light of a specific wavelength. The therapy results in a sequence of photochemical and photobiological processes causing irreversible photodamage to tumour tissues (12). SDT is a related procedure using ultrasound to produce other cytotoxic effects (Dougherty et al. 199).

In our study we investigated the DNA fragmentation, cell viability and ROS production of the HeLa cells treated with PDT and PDT followed after SDT. The second-generation photosensitizer $\mathrm{ClAlPcS}_{2}$ was employed and LEDs served as the source of radiation to elicit PDT.

The DNA fragmentation was investigated using the comet assay. Although phatolycanines are mainly localized in mitochondria and lysosomes there are evidences of their presence in nucleus and plasma membrane (Ndhundhuma et al. 2011, Castano et al. 2004). Ultrasound alone caused only slight DNA fragmentation which could be explained by shearing/denaturing of DNA through cavitation (Yu et al. 2004). Nevertheless, we detected a massive DNA fragmentation after PDT followed by SDT for $0.5 \mu \mathrm{M}$ concentration compared to solely PDT treatment. Previous results suggest that SDT forms internal cavitations resulting in water pyrolysis which generates hydrogen atoms and hydroxyl radicals (Rosenthal et al. 2004). It was shown that DNA bases (pyrimidine and purine) can be damaged by sonolyticaly generated hydroxyl radicals which could explain higher DNA fragmentation after PDT followed after SDT (Kondo et al. 1988). For example, superoxide can directly disrupt large molecules such as proteins and nucleic acids resulting in DNA damage ( $\mathrm{Yu}$ et al. 2004). Another explanation justifying higher DNA fragmentation after combined SDT and PDT could be activation of tumoursuppressor $\mathrm{p} 53$ protein involved in apoptotic processes. It was shown that SDT activates p53 and that extent of the DNA fragmentation depends on the activation time, the earlier the p53 activation, the higher the DNA fragmentation (Tang et al. 2011).

It is widely accepted that PDT is responsible for producing ROS, particularly singlet oxygen. SDT also exhibits the ability to produce free radicals initiating chain peroxidation of membrane lipids via peroxyl and/or alcoxyl radical leading to physical destabilization of the cell membrane (Rosenthal et al. 2004). ROS generation strongly influences crucial cellular processes such as protein phosphorylation, DNA synthesis, gene expression or apoptosis (Hoidal 2001). Some studies suggest that the main ROS for SDT-induced apoptosis is hydroxyl radical (Yu et al. 2004, Rosenthal et al. 2004)

In our study ultrasound alone showed only slight increase in ROS production. On the other hand, the cells treated with PDT and SDT caused higher ROS 
production compared to the cell treated only with PDT. It could be explained by formation of ROS by pyrolysis induced hemolytic bond cleavage (Rosenthal et al. 2004). One of the localization sites of phtalocyanines are mitochondria and it is known that ROS have a short lifetime thus they can only damage molecules in short diffusion distance from the sonosensitizer localization. (Lahm et al. 2001, Kinoshita and Hynynen 2006). There are studies linking the ROS production after SDT with the loss of mitochondrial membrane potential (Cheng et al. 2013). The loss of mitochondrial membrane potential inhibits the function of adenosine triphosphate synthesis resulting in the release of cytochrome $\mathrm{c}$ and subsequent activation of caspace- 9 and caspase- 3 which eventually leads to regulated cell apoptosis (Ji et al. 2006, Ly et al, 2003).

Ultrasound presents the physical-mechanical factor disrupting a cell structure. Microscopy images of the cell after PDT followed after SDT treatment proved more substantial damage to cellular membrane. We can hypothesize that SDT could result in higher porosity of cell membranes which consequently leads to a higher uptake of a photosensitizer in the tumourous cell (Bernard et al. 2010). Our results show that irreversible changes of the cell structure by a combination of PDT followed after SDT led to lower cell viability, especially for $0.5 \mu \mathrm{M}$ concentration, in comparison with PDT. Previous research carried out on solid tumour suggested that synergic effect of $\mathrm{ClAlPcS}_{2}$ and ultrasound resulted in diminishing tumour size after SDT and thus $\mathrm{ClAlPcS}_{2}$ could acts like a sonosensitizer (Yumita et al. 2004). EC 50 which determines the concentration of $50 \%$ cell survival was approximately 3-fold lower for the PDT followed after SDT in opposite to PDT treatment.

In conclusion, we assume that combination of mechanical ultrasound cell damage combined with increased ROS production is responsible for higher DNA fragmentation and consequently cell death. Our results indicate that synergic combination of PDT followed after SDT enhances a cytotoxic effect on HeLa cells with $\mathrm{ClAlPcS}_{2}$ as the sensitizer.

\section{Conflict of Interest}

There is no conflict of interest.

\section{Acknowledgements}

This work was supported by the grants from the Ministry of Education, Youth and Sports of the Czech Republic LO1304, LM2015062, European Regional Development Fund CZ.02.1.01/0.0/0.0/16_019/0000868 and Palacky University Olomouc IGA_LF_2019_004.

\section{References}

BERNARD V, ŠKORPÍKOVÁ J, MORNSTEIN V, SLANINOVÁ I: Biological effects of combined ultrasound and cisplatin treatment on ovarian carcinoma cells. Ultrasonics 50: 357-362, 2010.

BROOKER RJ: Genetics: analysis and principles (4th ed.). McGraw-Hill Science. New York, 2011.

CASTANO AP, DEMIDOVA TN, HAMBLIN MR: Mechanisms in photodynamic therapy: part one-photosensitizers, photochemistry and cellular localization. Photodiagn Photodyn Ther 1: 279-293, 2004.

CHENG J, SUN X, GUO S, CAO W, CHEN H, JIN Y, LI B, LI Q, WANG H, WANG Z, ZHOU Q, WANG P, ZHANG Z, CAO W, TIAN Y: Effects of 5-aminolevulinic acid-mediated sonodynamic therapy on macrophages. Int J Nanomedicine 8: 669-676, 2013.

COLLINS AR: The comet assay for DNA damage and repair (Review). Mol Biotechnol 26: 249-261, 2004.

DEVASAGAYAM TPA, TILAK JC, BOLOOR KK, SANE KETAKI S, GHASKADBI SAROJ S, LELE RD: Free Radicals and Antioxidants in Human Health: Current Status and Future Prospects. J Assoc Physic India 52: 796, 2004.

DOUGHERTY TJ, GOMER CJ, HENDERSON BW, JORI G, KESSEL D, KORBELIK M, MOAN J, PENG Q: Photodynamic therapy. J Natl Cancer Inst 90: 889-905, 1998.

HARTMANN A, AGURELL V, BEEVERS C, BRENDLER-SCHWAAB S, BURLINSON B, CLAY P, COLLINS A, SMITH A, SPEIT G, THYBAUD V, TICE RR: Recommendations for conducting the in vivo alkaline comet assay. Mutagenesis 18: 45-51, 2003.

HEATON PR, RANSLEY R, CHARLTON CJ, MANN SJ, STEVENSON J, SMITH BHE, RAWLINGS JM, HARPER EJ: Application of Single-Cell Gel Electrophoresis (Comet) Assay for Assessing Levels of DNA Damage in Canine and Feline Leukocytes. J Nutr 132: 1598S-1603S, 2002. 
HOIDAL JR: Reactive oxygen species and cell signalling. Am J Respir Cell Mol Biol 25: 661-663, 2001.

JI Z, YANG G, VASOVIC V, CUNDERLIKOVA B, SUO Z, NESLAND JM, PENG Q: Subcellular localization pattern of protoporphyrin IX is an important determinant for its photodynamic efficiency of human carcinoma and normal cell lines. J Photochem Photobiol B 84: 213-220, 2006.

JIANG Z, SHAO J, YANG T, WANG J, JIA L: Pharmaceutical development, composition and quantitative analysis of phthalocyanine as the photosensitizer for cancer photodynamic therapy. J Pharm Biomed Anal 87: 1898-1104, 2014.

KESSEL D, JEFFERS R, FOWLKES JB, CAIN C: Effects of sonodynamic and photodynamic treatment on cellular thiol levels. J Photochem Photobiol B: Biology 32: 103-106, 1996.

KINOSHITA M, HYNYNEN K: Mechanism of porphyrin-induced sonodynamic effect: possible role of hyperthermia. Radiat Res 165: 299-306, 2006.

KONDO T, KRISHNA CM, RIESZ P: Sonolysis, radiolysis, and hydrogen peroxide photolysis of pyrimidine derivatives in aqueous solutions: a spin-trapping study. Radiat Res 116: 56-73, 1988.

KUMARAVEL TS, VILHAR B, FAUX SP, JHA AN: Comet Assay measurements: a perspective. Cell Biol Toxicol 25: 53-64, 2009.

LAM M, OLEINICK NL, NIEMINEN A-L: Photodynamic therapy induced apoptosis in epidermoid carcinoma cells: Reactive oxygen species and mitochondrial inner membrane permeablization $J$ Biol Chem 276: 47379-47386, 2001.

LY JD, GRUBB DR, LAWEN A: The mitochondrial membrane potential (deltapsi(m)) in apoptosis; an update. Apoptosis 8: 115-128, 2003.

MENG QQ, CHEN BA, WU W, SHAO Z, GAO F, ZHAO H: Antitumor effects of low-frequency ultrasound combined with adriamycin on human leukemia multidrug resistance cell line K562/A02. (In Chinese) Chinese J Cancer 27: 1182-1185, 2008.

NDHUNDHUMA I, HAUSER C, SCALFI-HAPP C, RÜCK A, STEINER R: Subcellular co-localization of aluminum (III) phthalocyanine chloride tetrasulphonate with fluorescent markers in the human melanoma cell-line HT-144. Med Laser Appl 26: 93-100, 2011.

ÖSTLING O, JOHANSON KJ: Microelectrophoretic study of radiation-induced DNA damages in individual mammalian cells. Biochem Biophys Res Commun 123: 291-298, 1984.

ROSENTHAL I, SOSTARIC JZ, RIESZ P: Sonodynamic therapy - a review of the synergistic effects of drugs and ultrasound. Ultrason Sonochem 11: 349-363, 2004.

SEKKAT N, VAN DEN BERGH H, NYOKONG T, LANGE N: Like a bolt from the blue: phthalocyanines in biomedical optics. Molecules 17: 98-144, 2011.

SINGH NP, MCCOY MT, TICE RR, SCHNEIDER EL: A simple technique for quantitation of low levels of DNA damage in individual cells. Exp Cell Res 175: 184-191, 1988.

TANG W, FAN W, LIU Q, ZHANG J, QIN X: The role of p53 in the response of tumor cells to sonodynamic therapy in vitro. Ultrasonics 51: 777-785, 2011.

YU T, WANG Z, MASON TJ: A review of research into the uses of low level ultrasound in cancer therapy. Ultrason Sonochem 11: 95-103, 2004.

YU T, BAI J, HU K, WANG Z: The effect of free radical scavenger and antioxidant on the increase in intracellular Adriamycin accumulation induced by ultrasound. Ultrason Sonochem 10: 33-35, 2003.

YUMITA N, UMEMURA S: Sonodynamic antitumour effect of chloroaluminum phthalocyanine tetrasulfonate on murine solid tumour. J Pharm Pharmacol 56: 85-90, 2004. 